\section{UCDNN}

LIBRARY
University of Connecticut OpenCommons@UConn

Faculty Articles and Papers

School of Law

2006

\title{
Causing Death for Compassionate Reasons in American Law
}

Richard Kay

University of Connecticut School of Law

Follow this and additional works at: https://opencommons.uconn.edu/law_papers

Part of the Criminal Law Commons, and the Health Law and Policy Commons

\section{Recommended Citation}

Kay, Richard, "Causing Death for Compassionate Reasons in American Law" (2006). Faculty Articles and Papers. 253.

https://opencommons.uconn.edu/law_papers/253 


\section{HEINONLINE}

Citation: 54 Am. J. Comp. L. 6932006

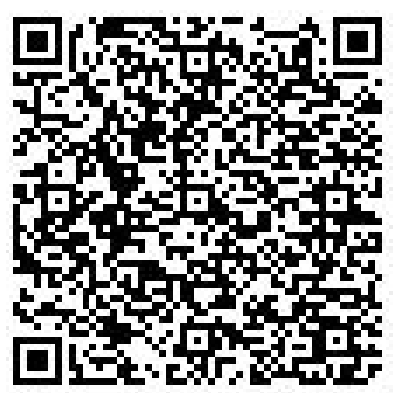

Content downloaded/printed from

HeinOnline (http://heinonline.org)

Tue Aug 16 12:52:54 2016

-- Your use of this HeinOnline PDF indicates your acceptance of HeinOnline's Terms and Conditions of the license agreement available at http://heinonline.org/HOL/License

-- The search text of this PDF is generated from uncorrected OCR text.

-- To obtain permission to use this article beyond the scope of your HeinOnline license, please use:

https://www.copyright.com/ccc/basicSearch.do?

\&operation $=$ go\&search $\mathrm{Type}=0$

\&lastSearch $=$ simple\&all=on\&titleOrStdNo=0002-919X 


\section{RICHARD S. KAY*}

\section{Causing Death for Compassionate Reasons in American Law}

There is no single American law on causing death for compassionate reasons. The federal distribution of powers leaves the relevant areas of law mainly to the states. Federal constitutional law has been invoked only in connection with the outer limits within which state law may govern. So far it has not been successfully employed to invalidate state regulation. Consequently, there are at least 50 laws dealing with end-of-life decisions. Nevertheless, the basic organization of the legal issues has turned out to be similar in almost all American jurisdictions and I will treat the subject generally. It is important to be mindful, however, that, in this respect. I have adopted a significant simplification in order to facilitate exposition.

\section{The Law and Practice of Compassionate Death}

Like every modern society, the United States has struggled with end-of-life problems. Medical science is now capable of maintaining heart and lung function and some brain activity-and, therefore, life, as defined in law-even in people incapable of the simplest human activities. ${ }^{1}$ The same technology maintains the lives of competent terminally ill people suffering extreme pain, discomfort and loss of dignity. Sometimes, it is understandable that individuals, families and physicians may judge death to be an improvement.

There is evidence that, in such cases, patients and other concerned parties are acting on that judgment by removing "life-sustaining" devices such as ventilators or feeding tubes. Such actions are lawful throughout the United States, if made by the appropriate persons, for specified reasons, using the right procedures. Beyond this, in a non-trivial number of cases, patients, their doctors or their family members appear to be acting affirmatively to end lives, something that, except in one jurisdiction, is always unlawful. A survey of al-

* George and Helen England Professor of Law, University of Connecticut School of Law. I am grateful to Carol Weisbrod for valuable advice and to Robert Dunn and Carrie Field for helpful research and editing assistance.

1. Approximately 30 states have adopted statutes recognizing "brain death," essentially irreversible cessation of all brain function. This replaced definitions turning on the cessation of heartbeat or breathing. The Law Dictionary, LEXIS, Anderson Publishing Co. (2002). 
most 2000 physicians found that 18 percent were willing to violate the law by prescribing lethal drugs or administering lethal injections. ${ }^{2}$

It is reasonable to believe that physician-assisted suicide, as well as active euthanasia, occurs in hundreds if not thousands of cases every year. Yet there are few prosecutions. In cases where all the relevant parties are in accord, it is understandable that law enforcement authorities never hear of these deaths. ${ }^{3}$ Only rarely do prosecutors choose to initiate legal proceedings even when such cases are brought to their attention. ${ }^{4}$ In the small number of cases when doctors are brought to trial, convictions turn out to be exceptional. Juries sometimes ignore judges' instructions and revert to a more rudimentary sense of right and wrong. ${ }^{5}$ And, in the few cases of conviction for euthanasia or assisting suicide in the kinds of circumstances discussed, lenient sentencing is common. ${ }^{6}$

\section{Homicide AND SUICIDE}

It is not a sufficient defense in a homicide persecution to prove that the killing was undertaken with a benign motive. The "malice aforethought" required for a murder conviction is a term of art and does not refer to hostility toward the victim. ${ }^{7}$ Similarly, a defense of consent is unavailable in a homicide prosecution. ${ }^{8}$ Taking life is not a mere private wrong. Common law presumed that an individual's life belonged as much to God as to the person him or herself. In listing the prohibitions of the natural law that preceded organized society, Locke mentioned first the prohibition against taking life, reasoning that men were " $[\mathrm{H}]$ is property, whose workmanship they are, made to last during His, not another's pleasure."9

2. Diane E. Meier, et.al., A National Survey of Physician-Assisted Suicide and Euthanasia in the United States, 338 NEw. ENG. J. MED. 1193, 1193 (1998). Another study reported that $22.5 \%$ of oncologists surveyed supported, and $14.5 \%$ had actually participated in, causing such deaths. Ezekiel J. Emanuel, et.al., Attitudes and Practices of U.S. Oncologists Regarding Euthanasia and Physician Assisted Suicide, 133 ANNALS OF INTERNAL MED. 527, 529 (2000). The attitudes of physicians appear to vary by specialty. Meier, supra at 1199 . A survey of physicians treating AIDS patients showed much larger percentages who supported, and who had approved, patient requests for lethal prescriptions. Lee R. Slome, et.al., Physician-Assisted Suicide and Patients with Human Immunodeficiency Virus Disease, 336 NEw. ENG. J. MED. 417, 419-20 (1997).

3. See generally Stephen J. Ziegler, Physician-Assisted Suicide and Criminal Prosecution: Are Physicians at Risk? 33 J.L. MED. \& ETHICs 349 (2005).

4. Id. at 355.

5. See Julia Pugliese, Don't Ask - Don't Tell: The Secret Practice of PhysicianAssisted Suicide, 44 Hastings L.J., 1291, 1298-99.

6. Id.

7. E.g. People v. Conley, 411 P.2d 911, 918 (Cal. 1966).

8. Washington v. Glucksberg, 521 U.S. 702, 710-11 (1997). For a recent statement see Sanders v. Wyoming, 7 P.3d 891, 894-95 (Wyo. 2000).

9. JoHN Locke, Treatise of Civil Government and A LeTter Concerning TolERATION 6 (Charles Sherman ed., Appleton-Century Crofts 1937) (1689). 
Therefore, no exception to the homicide law was made for suicide. The objections to consent as a defense to homicide apply: An individual's life is not solely his or her own concern. Individuals are not authorized to deprive the king or society of their presence in the world. Destruction of one's own life is an affront to God who is the sole judge of life and death. Blackstone called suicide a "double offence; one spiritual, in invading the prerogative of the Almighty, and rushing into his immediate presence uncalled for, the other temporal, against the king, who hath an interest in the preservation of all of his subjects ...."10 It is apparent that legal hostility to suicide has always been tied to basically religious ideas of the inviolability of human life, an association that has continued to the present, sometimes expressed overtly and sometimes implicitly.

The crime of suicide was imported into the American legal systems with the rest of the common law. Suicide had two penal consequences. The suicide's body was subjected to an "ignominious burial." This generally consisted of burial at a crossroads on the highway with a stake driven through the body. Second, the personal (although not the real) property of the suicide was confiscated. The obvious criticisms of these punishments-as a senseless superstition in one case and as unjust to the heirs of the suicide in the other-led to their early modification. By the end of the eighteenth century punishments for suicide were widely abandoned. Several states enacted explicit prohibitions on using them. ${ }^{11}$

The withdrawal of penalties for suicide, however, did not immediately extend to attempted suicide. There, the wrongdoer was still available for punishment. As late as 1961, the North Carolina Supreme Court affirmed the misdemeanor conviction of a defendant who survived "slashing and cutting his throat and ... hanging himself from a barn rafter." The court did sheepishly point out that such offenders might be placed on probation or remitted to appropriate "state facilities and services."12 Most jurisdictions, however, have long treated attempted suicide as indication of mental illness not criminality. The Commentary to the Model Penal Code found it implausible to suppose that criminal sanctions would deter many people set on suicide and it found that criminalization exhibited a "certain moral extravagance."13 Prosecutions for attempting suicide have now entirely disappeared. ${ }^{14}$

In contrast, over the same period, the criminality of assisting a suicide has been reinforced. Unlike suicide and attempted suicide-

10. William Blackstone, 4 Commentaries *189.

11. Thomas Marzen, et.al., Suicide: A Constitutional Right?, 24 DUQ. L. REv. 1, 67-69 (1985).

12. State v. Willis, 121 S.E. $2 d 854,857$ (N.C. 1961).

13. Quoted in In re Joseph G, 667 P.2d 1176, 1178 (Cal.1983).

14. John F. Kennedy Mem'l Hosp. v. Heston, 279 A.2d 670, 672 (N.J. 1971). 
an actual offender is present and the presumption of mental incapacity is inapt. ${ }^{15}$ In 1997, the United States Supreme Court noted that 46 states, the District of Columbia and two territories had laws against assisted suicide. ${ }^{16}$ Such laws, however, did not impose the severe penalties attached to homicide. ${ }^{17}$

Over time, therefore, suicide and participation in suicide have been viewed as less and less culpable. Nevertheless, court after court has repeated that the law still regards decisions to end human life, with or without the assent of the individual involved, as profoundly anti-social. The decisions not to punish actions associated with suicide are explained as motivated by concerns apart from and despite its fundamentally immoral character. The United States Supreme Court's in Washington v. Glucksberg in 1997 reflected the prevalent judicial attitude: "[O]pposition to and condemnation of suicide-and, therefore, of assisting suicide-are consistent and enduring themes of our philosophical, legal and cultural heritages."18 In that judgment the Court held that the right to personal autonomy associated with the Fourteenth Amendment to the United States Constitution did not encompass a right to end one's own life. ${ }^{19}$

The only prominent exception is Oregon's 1999 adoption of the Right to Death With Dignity Act. This legislation establishes a right to cause one's own death in strictly defined circumstances. It creates an elaborate procedure to ensure the considered and voluntary nature of the action. In the first six years in which the Act was in effect, 265 lethal prescriptions were reported, of which 171 were used to commit suicide. ${ }^{20}$ The United States Supreme Court has upheld the Act against a claim by the federal government that it was inconsistent with federal law regulating the prescription of drugs by physicians. $^{21}$ While the legal grounds of this litigation concern only issues of federalism and statutory construction, the interest of the current

15. In re Ryan N., 112 Cal. Rptr. 2d 620, 631 (Cal. Ct. App. 2001).

16. Glucksberg, 521 U.S. at 711; See also Marzen, supra note 11 at 73-77.

17. In re Joseph G, 667 P.2d 1176, 1179 (Cal. 1983).

18. 521 U.S. at 711.

19. Id. at 776-77. The autonomy right mentioned is commonly referred to as a right to "privacy". See Erwin Chemerinsky, Constitutional Law Principles aND Policies 784-787 (Aspen Law \& Business 2d ed. 2002). Arguments for such a constitutional right have been a persistent feature of the academic literature for many years. See, e.g. Edward M. Kay, Right to Die 18 U. FLA. L. REv. 591 (1965-66) (associating such a right with the Ninth Amendment); David A. Pratt, Too Many Physicians: Physician-Assisted Suicide After Glucksberg/Quill, 9 ALB. L.J. ScI. \& TeCH. 161 (associating it with the Fourteenth Amendment.). For extended arguments to the contrary see Marzen, supra note 11 at 105-107.

20. Susan M. Wolf, Physician-Assisted Suicide, 21 Clinics in Geriatric Med.179, 185 (2005).

21. Gonzales v. Oregon, No. 04-623, 2006 U.S. LEXIS 767 (Jan. 17, 2006). 
federal administration in pursuing it is generally assumed to be its hostility to state approval of any form of suicide. ${ }^{22}$

\section{The Right to Refuse Treatment}

Notwithstanding the almost uniform rejection of any right of suicide, many judicial opinions confirm the legality of actions by health providers and others undertaken to end the suffering of grievously impaired patients by discontinuing the treatments or procedures that are keeping them alive. These judgments emphatically reject the suggestion that they condone a right to die. They rest on a different right-the right to control one's own body and, more specifically, to refuse or to discontinue medical treatment.

This right is well settled in common law. In a much cited dictum, Judge Cardozo (as he was then) affirmed that an unauthorized surgery was an actionable trespass: "Every human being of adult years and sound mind has a right to determine what shall be done with his own body; and a surgeon who performs an operation without his patient's consent, commits an assault, for which he is liable in damages. ${ }^{23}$ From this it follows that a patient has the right to refuse any procedure and, by the same reasoning, to require it to be discontinued. Most state legislation on termination of life-saving procedures, as will be discussed in the next section, are directed at the problem of making such decisions for incompetents. But, in protecting the right to discontinue treatment for an incompetent person, they presuppose (and sometimes explicitly state) that the same right is enjoyed by competent persons. ${ }^{24}$

This common law right has now been widely recognized as constitutionally protected. In 1990, in Cruzan v. Director, Missouri Department of Health the United States Supreme Court confirmed Missouri's right to forbid termination of life-preserving treatment without clear evidence that the incompetent patient, when competent, had expressed a preference for such a course of action. The Court assumed, but did not hold, that the right to refuse treatment was part of the liberty that the Fourteenth Amendment requires not

22. Department of Justice Press Release, Assistant Attorney General Mccallum's Statement Regarding the District Court Ruling on Assisted Suicide in Oregon, http:// www.usdoj.gov/opa/pr/2002/April/02_ag_231.htm (last visited Oct. 27, 2005) (stating "a just and caring society should do its best to assist in coping with the problems that afflict the terminally ill. It should not abandon or assist in killing them").

23. Schloendorff v. Society of the New York Hospital, 105 N.E. 92, 93 (N.Y. 1914)

24. See e.g. W.VA. CoDE. \& 16-30(2)(b)(1) (2005) (stating "Common law tradition and the medical profession in general have traditionally recognized the right of a capable adult to accept or reject medical or surgical intervention affecting one's own medical condition"). 
be infringed without special justification. ${ }^{25}$ State cases have cited both common law and constitutional bases for the right. Little seems to hinge on which source is emphasized. ${ }^{26}$

The right to refuse treatment effectively empowers a terminal patient in distress to discontinue the processes prolonging his or her life. In neither common law nor constitutional form, however, is the right absolute. Courts have recognized several countervailing state interests that might be invoked to block its exercise. Those interests fall under four headings: (1) maintaining the ethical integrity of the medical profession; (2) the protection of the interests of innocent third parties; (3) the preservation of life; and (4) the prevention of suicide. $^{27}$ I will briefly discuss the first three in the following paragraphs, deferring consideration of the last, preventing suicide, until the next section.

\section{(1) Maintaining the Ethical Integrity of the Medical Profession}

The interest in the integrity of the medical profession was important to the Supreme Court of New Jersey in upholding the appointment of a guardian for an accident victim who was a member of the Jehovah's Witnesses. The guardian was empowered to, and did, consent on her behalf to a blood transfusion necessary to save her life. ${ }^{28}$ The court found that hospitals and doctors were the "involuntary hosts" of severely ill patients. Doctors are committed by their professions to "to aid the sick and injured." They are "consecrated to preserving life." To require them to perform surgery in circumstances that unnecessarily endanger the patient's life is to put them under an unacceptable strain. Refusing treatment also requires health care providers to make difficult judgments about the competence of patients-and to risk civil liability if they guess wrong. ${ }^{29}$ In most cases, however, the state's interest in the integrity of the medical profession has been easily dismissed. Courts cite ample material showing that professional standards actually approve acceding to a patient's request to end treatment. In addition, they hold that the individual's

25. 497 U.S. $261,278-80,282$ (1990). What the court said was "The principle that a competent person has a constitutionally protected liberty interest in refusing unwanted medical treatment may be inferred from our prior decisions." Id. at 278 .

26. Compare In re Quinlan, 355 A.2d 647 (N.J. 1976) (constitutional) with In re Longway, 549 N.E. 2 d 292 (Ill. 1990) (common law).

27. The most frequently cited authority for this categorization is Superintendent of Belchertown State School v. Saikewicz, 370 N.E.2d 417, 425 (Mass. 1977). See, e.g. Cruzan, 497 U.S. at 271. I have altered the order in which the Saikewicz court presented the interests for the purpose of exposition.

28. John F. Kennedy Mem'l Hosp., 279 A. 2d at 671. The refusal had been expressed at the time by the patient's mother. Id. at 671 . Another aspect of this argument is that the involvement of the physician in causing the death of the patient undercuts patients' confidence, possibly endangering public health. Sampson \& Doe v. State, 31 P.3d 88, 96 (Alaska 2001).

29. John F. Kennedy Mem'L Hosp. 297 A.2d at 673. 
right to refuse is more important, and outweighs, the physician's interest in maintaining nice ethical principles. ${ }^{30}$

\section{(2) The Protection of the Interests of Innocent Third Parties}

The state interest in the protection of third parties has typically been invoked in the case of a non-terminal patient with dependent children. Two cases have actually approved involuntary treatment to prevent "abandonment" of minor children. Both involved refusal of blood transfusions on religious grounds, where the patient had a good prospect of recovery. ${ }^{31}$ But courts have upheld the right to end treatment if there is another parent or an extended family to care for the children. ${ }^{32}$ The state's interest seems mainly to be discussed by courts reconfirming the right to refuse treatment in cases where there are no dependents. ${ }^{33}$ More significantly, the termination of treatment cases disproportionately concern patients who, because of age or because of long-term incapacity, are unlikely to raise this problem.

\section{(3) The Preservation of Life}

The state's interest in the preservation of life similarly appears more the object of recitation than of application. The United States Supreme Court noted that the states-like "all civilized nationsdemonstrate their commitment to life by treating homicide as a serious crime."34 Still, this generalized interest is regularly found to be outweighed by the patient's "autonomy" right to stop treatment. Courts weighing the various interests have often disparaged the state's interest in these cases as a short postponement of the imminent and inevitable. ${ }^{35}$ Courts also often doubt that the state has any substantial interest in the preservation of life apart from the interest of the individual involved. They thus espouse, sometimes explicitly, a classic liberal conception of the state, going so far in one case to quote

30. E.g. Rasmussen v. Fleming, 741 P.2d 674, 684-85 (Ariz. 1987).

31. Application of the President and Dirs. of Georgetown College, 331 F.2d 1000 (D.C. Cir. 1964); In re Winthrop Univ. Hosp., 490 N.Y.S.2d 996 (N.Y. App. Div. 1985).

32. See e.g. Fosmire v. Nicoleau, 551 N.E. 2d 77 (N.Y. 1990) (a surviving parent); Public Health Trust of Dade County v. Wons, 541 So. 2d 96 (Fla. 1989) (extended family). Both cases dealt with blood transfusions refused by Jehovah's Witnesses. In both the patient's right to refuse treatment was confirmed only after the transfusions had been administered over the patient's objections and the matter was decided without the threat of anyone's imminent demise.

33. E.g. Rasmussen, 741 P.2d at 685.

34. Cruzan, 497 U.S. at 280.

35. See e.g. In re Quinlan, 355 A.2d at 664; Brophy v. New Eng. Sinai Hospital, 497 N.E. 2d 626, 635 (Mass. 1986). Likewise, state statutes regulating termination of medical procedures for incompetent patients often require that the patient be in a terminal condition or in a "persistent vegetative state." E.g. FLA. STAT. \$\$ 765.302, 765.305 (2005). 
John Stuart Mill. ${ }^{36}$ Once we have dispensed with claims based on the rights of doctors or other third parties, the interest of the state in this self-regarding conduct more or less disappears.

The result of the judicial treatment of these countervailing state interests is that there is almost no set of circumstances where a competent individual will not have the right to refuse or discontinue any medical procedure, no matter how effective it promises to be, and no matter how drastic the consequences of declining it. In one case, a 28 year old woman was held entitled to discontinue a nasogastric feeding tube. She was a quadriplegic suffering from cerebral palsy, bedridden with almost no ability to care for herself and had suffered several family misfortunes. "She [had] on several occasions expressed the desire to die." 37 She was also college educated and, according to the court, "intelligent, very mentally competent." Doctors forecast that removing the tube would create a serious threat to her life; with it she would probably live another 15 or 20 years.

This characterization of American law must be qualified in one way. There has been some queasiness about applying the broad right to discontinue medical treatment to the use of devices to deliver food and water to the patient. Cutting off these basic requirements of life, no matter how delivered, raises associations with the everyday comforts of eating and drinking, and has therefore, a more powerful emotional impact. 38 During the well-publicized controversy over maintaining a gastrostomy tube for Terri Schiavo, who had been in a persistent vegetative state for 15 years, the Governor of Florida, complained of "a rush to starve her to death." 39 Although medical opinion regards the use of intravenous hydration and tube-delivered nutrition as extraordinary medical procedures, some studies have

36. Brophy, 497 N.E.2d at 633 ; See also Thor v. Superior Court, 855 P. 2d 375, 384 (Cal. 1993); Fosmire, 551 N.E. 2d at 81-82) (declaring "the State rarely acts to protect individuals from themselves, indicating that the State's interest is less substantial when there is little or no risk of direct injury to the public").

37. Bouvia v. Superior Court, 225 Cal. Rptr. 297, 299-300 (Cal. Ct. App.1986). See also Lane v. Candura, 376 N.E.2d 1232 (Mass. 1978). (Approving termination of treatment for a patient who did not fear death but welcome[d] it." Id. at 1234.). See Howard Brody, Physician-Assisted Suicide in the Courts: Moral Equivalence and Double Effect in Clinical Practice, 82 MrNN. L. REv. 929, 939 (1997-98) (discussing refusal of treatment by suicidal patients).

38. David Orentlicher \& Christopher M. Callahan, Feeding Tubes, Slippery Slopes and Physician-Assisted Suicide, 25 J. Legal MED. 398-99 nn.70-74 (2004); James F. Childress, When Is It Morally Justifiable to Discontinue Medical Nutrition and Hydration? in By No Extraordinary Means: The Choice to Forgo Life-SusTAINING FOOD AND WATER, 67, 73-74 (Joanne Lynn, ed. 1986).

39. http://www.cbsnews.com/stories/2005/03/19/national/main681754.shtml (last visited Jan. 11, 2006); John Schwartz, Neither 'Starvation' Nor the Suffering It Connotes Applies to Schiavo, Doctors Say, N.Y. Times, March 25, 2005, at A14. 
found that physicians appear more reluctant to terminate those procedures, than others such as respirators or dialysis. ${ }^{40}$

Most courts have refused to make this distinction, treating artificial hydration and nutrition as medical procedures that may be discontinued on the proper consent. The United States Supreme Court in Cruzan assumed as much. ${ }^{41}$ There appears to be no appellate judgment in any jurisdiction in which the termination of life-sustaining procedures was denied on the particular ground that the right to refuse treatment did not extend to the provision of food and nourishment. ${ }^{42}$ Dissenting opinions, however, have sometimes shown a keen aversion to allowing this kind of death. In a recent Kentucky judgment a dissenting justice railed that "removing lifeprolonging treatment from a person who is permanently unconscious' ... all sounds so nice. .." but "removing food, water and any air from a living person is an atrocity." 43

Such arguments have persuaded some legislatures. For the most part, statutes authorizing termination of medical treatments for incompetent patients explicitly include termination of artificial methods of hydration and nutrition. ${ }^{44}$ Some later statutes, however, require more care before authorizing removal of nutrition and hydration. These range from simply mentioning them separately from other life-prolonging procedures ${ }^{45}$ to restricting the decision makers, who may consent to "withdraw[al] [of] artificial administration of food or fluid." 46 The Iowa statute excludes provision of nutrition and hydration from its definition of "life-sustaining procedures," removing them even from the scope of procedures that might be governed by the patient's own advance declaration. ${ }^{47}$ In the wake of the controversy over Terri Schiavo, many further restrictions on terminating the provision of food and water have been introduced into state legislatures. ${ }^{48}$ So far, however, all of these developments, leave untouched the near total right of a competent patient to refuse any medical procedure including the provision of nutrition and hydration.

40. American Medical Association, Council on Ethical and Judicial Affairs, March 15,1986 quoted in In re Guardianship of Barbara Grant, 747 P.2d 445, 454 (Wash. 1987); Orentlicher \& Callahan, supra note 38 at $399 \mathrm{nn} .70-71$.

41. Cruzan, 497 U.S. at 279, 288-89 (O'Connor, J. concurring), 307 (Brennan J. joined by Marshall, J. dissenting).

42. That was the conclusion in 1988 of the Maryland Attorney General cited in Mack v. Mack, 618 A.2d 744, 756-57 (Md. 1993).

43. Woods, 142 S.W.3d at 99-100 (Wintersheimer, J. dissenting) (Ky. 2004).

44. See, e.g. Ala. Code. § 22-8A-4 (2005); CAL. Prob. Code, § 3200 (West 2000); FLa. STAT. \& 765.101(10) (2005).

45. The North Carolina law provides an authorized, but non-exclusive, form for an Advanced Health Care Directive that treats "extraordinary means" and "artificial nutrition and hydration" separately. N.C. GEN STAT.\$ 90-321 (d).

46. ARIz. REv. STAT. \& 36-3231(D) (2005).

47. IOWA CODE, \& 144A.2(8)(b) (2004).

48. Shaila Dewan et al., States Taking a New Look at End-of-Life Legislation, N.Y. Times, Mar. 31,2005 at A14. 


\section{Refusing Treatment, Suicide, Assisted Suicide aND Euthanasia}

This broad, and largely unqualified, right is difficult to reconcile with recognition of the countervailing state interest in "preventing suicide." Courts continue to affirm the importance of the state's policy against suicide. Unlike the other interests discussed, however, they do not usually weigh this interest against the right of the individual. Instead, they deny that the action contemplated involves any risk of suicide at all.

In the California case considered above, in which the Court approved the removal of the feeding tube from a profoundly disabled woman, it determined that-independently of the mechanical feeding-her life had "been diminished to the point of hopelessness, uselessness, unenjoyability and frustration." It was "incongruous, if not monstrous, for medical practitioners to assert their right to preserve a life that someone else must live, or, more accurately, endure, for " 15 to 20 years." That "decision must ultimately belong to the one whose life is in issue...." Remarkably, however, the court then denied that the petitioner was, in effect, asking to commit suicide. Despite its own sympathetic evaluation of her reasons for not wanting to extend her life, the court concluded that she had "merely resigned herself to accept an earlier death, if necessary, rather than live by feedings forced upon her by means of a nasogastric tube." 49 The legal policy against suicide has also survived in state legislation regulating endof-life treatment decisions. These statutes routinely include a section declaring that nothing in the legislation condones or approves suicide, mercy killing and euthanasia. ${ }^{50}$

Two common distinctions between suicide and fatal discontinuation of treatment have been asserted. First, courts sometimes presume that patients in the latter case only want rid themselves of the medical treatment-not to end their lives. This rationale fits the judgments upholding the right of a Jehovah's Witness to refuse lifesaving blood transfusions arising while the patients were receiving other medical treatment. This demonstrated that the patient did not "wish to die, she wanted to live, but her faith demanded that she refuse blood even at the price of her life." 51 Refusing treatment may be independent of a desire to die whenever that choice "is reasonably motivated by a desire to avoid procedures that are in themselves, and not simply because they prolong a life, physically or emotionally pain-

49. Bouvia, 225 Cal. Rptr. at 304-06.

50. E.g. ARIz. REv. Stat. $\$ 36-3210$ (2005). A computer search of state statutes disclosed 24 States with these provisions. An obvious counter-example is the Oregon law on assisted suicide discussed above.

51. John F. Kennedy Mem'l Hosp., 279 A.2d at 673. 
ful."52 That characterization, however, fails to describe many of the judgments approving the termination of treatment where the main objection to the procedure was that it maintained a life that was painful and without meaningful satisfactions. ${ }^{53}$

The second ground of distinction asserts that suicide and euthanasia are affirmative acts that cause death but stopping a treatment simply removes an impediment to the progress of the underlying ailment. "Stopping the treatment," as one court said, merely "allows the delayed meeting with death to take place."54 The difficulties with this distinction are manifest. It supposes an ability to tell the difference between activities that do and do not interfere with natural death. It is not clear why the use of hand feeding, heating or air conditioning, or antiseptics, for example, fall into the first category.

It is hard, therefore, to defend a logical distinction between suicide-euthanasia and termination of life-support, at least in the context of the terminal and suffering patient. Some judges and commentators, however, have expressed reasons of policy for maintaining these two categories. The prospect of, say, physicians administering lethal doses of medicine to willing patients conjures up a "parade of horribles." These possibilities become more frightening when placed in the context, to be discussed in the next section, of unconscious or incompetent patients. Those cases are premised on what is an essentially fictional assent of the patient to stopping lifesupport. What would stop the same kind of fictional consent being recognized in cases where a court decides an incompetent patient ought to have consented. Add to this the fuzziness of the very idea of competence and we have, as one court put it, "the slippery slope with a vengeance." 55

All of these arguments featured in the United States Supreme Court's rejection of a direct challenge to the distinction between termination of life support and suicide-euthanasia in two cases decided in 1997. In both cases the claimants argued the unconstitutionality of prohibitions on assisted suicide. In the first, Washington v. Glucksberg, ${ }^{56}$ the criminal penalty was argued to be a deprivation of liberty without due process of law under the Fourteenth Amendment. That provision has been held to require especially pressing state reasons for restricting conduct within a realm of personal "privacy," meaning, in this context, the ability to control important and intimate aspects of one's own life. The Supreme Court had strongly intimated in Cruzan that this included the traditional right to control one's body

52. Guardianship of Jane Doe, 583 N.E. 2d 1263, 1275 (Mass. 1992) (O'Connor, J. dissenting).

53. These matters are further discussed in Section 6 below.

54. Donaldson v. Lundgren, 4 Cal. Rptr. 2d 59, 63 (Cal. Ct. App. 1992).

55. People v. Kevorkian, 639 N.W. 2d 291, 312 (Mich. Ct. App. 2001).

56. 521 U.S. 702 (1997). 
and, by extension, to refuse medical treatment even if doing so would hasten the death of the right-holder. Citing that decision, the claimants asserted a "liberty to choose how to die."

The Court held there was no "right to die" in the specially protected liberty of the Fourteenth Amendment. That rigorous protection was reserved for rights "deeply rooted in this Nation's history and tradition." The right to refuse treatment was well established in the common law; the right to commit suicide has never been legally protected-quite the contrary. ${ }^{57}$ The Court went on to reiterate concerns about the difficulty of limiting such activity to truly voluntary decisions of competent people. It cited statistics from the Netherlands showing that, despite the careful procedures provided in law, in one year almost 5000 people had received "lethal morphine overdoses" without having given explicit consent. It worried particularly about the vulnerability of "severely disabled neonates and elderly persons suffering dementia." 58

The second case, Vacco $v$. Quill, ${ }^{59}$ dealt even more directly with the need to distinguish discontinuing life-saving medical treatment from acts intended to induce death. This time the New York law on assisted suicide was attacked as a violation of the Fourteenth Amendment's Equal Protection Clause. The Court of Appeals had held that the state did "not treat equally all competent persons who are in the final stages of terminal illness and wish to hasten their deaths" and that this inequality was not rationally related to a legitimate state interest. ${ }^{60}$ The Supreme Court reversed. "[W]e think the distinction between assisting suicide and withdrawing life-sustaining treatment. . . is both important and logical. ..." It rehearsed some of the explanations already surveyed: The assisted suicide is killed by the medication; the untreated patient by the underlying disease; a physician assisting suicide "necessarily and indubitably intend[s] primarily that the patient be made dead: the physician who discontinues treatment may intend only to respect the patient's wishes" and "to cease doing useless and futile things to the patient." The Court also stressed the basic and immemorial legal distinction between identical acts undertaken for different reasons. ${ }^{61}$

It is fair to say that there is now near-unanimous agreement on two propositions: 1) Acts that end treatment and that will almost certainly lead to death are lawful and protected by constitutional right; 2) Intentional administration of treatment that will almost certainly lead to death is not a constitutional right and is, indeed, almost everywhere unlawful.

57. Id. at $724-25,727-28$

58. Id. at 734 .

59. 521 U.S. 793 (1997).

60. Id. at 798-99.

61. Id. at 800-03. 


\section{Rights of Incompetent Patients}

Having established these basic propositions, it is necessary to examine their application to cases in which the individual involved is either unconscious or without the mental capacity to make his or her own decisions. As may be imagined, when we are dealing with the late stages of fatal illness or accident, this is not an uncommon situation. Such cases, moreover, are more likely to bring the questions before the courts. As a practical matter, the express wishes of a competent patient in extremis will rarely be disputed by family members or physician. When the patient is unable to speak for him or herself, disagreements of the interested parties may be hard to resolve and the dispute may turn to litigation. Most recent legislation on the conditions for terminating life-support procedures has also been specially directed at the treatment of incompetent patients.

As with competent patients, the authority to terminate such procedures has been based on the patient's right to refuse treatment and not on any right to a speedy or comfortable death. ${ }^{62}$ It is treated, therefore, as an aspect of the right to self-determination. Incompetence, however, is nothing but the incapacity to make decisions. Speaking of persons incompetent because permanently in coma or in a persistent vegetative state, Laurence Tribe puts the matter mildly when he says that "the task of giving content to the notion that [such persons] have rights in the face of recognition that they could make no decisions about how to exercise any such rights, remains a difficult one."63

Nevertheless, courts have wasted little time in presuming that the right to discontinue treatment may be exercised by a surrogate on an incompetent's behalf, "[T] he state may not deprive citizens of their constitutional rights solely because they do not possess the decisional capacity to personally exercise them."64 The resulting jurisprudence has been formed - or deformed-by the effort to make surrogate decision-making consistent with the underlying premise of personal autonomy.

Both decisional and statutory law now recognize three ways to make this decision for the patient. Though very widely recognized, they differ somewhat in content and availability from jurisdiction to jurisdiction.

(1) The most favored procedure for making life-support decisions for incompetents is the express directive, executed by the patient when competent. These instructions take various forms and are given various names: grants of power of attorney, advance health

62. Cruzan, 497 U.S. at 277-79.

63. Laurence Tribe, American Constitutional Law, 1368 n.25 (Foundation Press 2d. ed. 1988).

64. Woods, 142 S.W.3d at 32. 
care directives, living wills. They are of two kinds. They may spell out the circumstances in which particular procedures may be used. Alternatively, they may designate an individual to make the decisions with or without providing substantive standards for that agent to apply. Modern state legislation on end-of-life treatment recognizes the validity of such directives, prescribes minimum standards of content and procedures for executing them, and regulates the occasions on which they may be put into effect. Commonly, they also provide an outline form of such an order that will satisfy the statute's requirements. ${ }^{65}$ There appears to be almost no litigation where such directives have been executed, indicating that they are more or less universally accepted.

This acceptance is consonant with the idea that the right to refuse treatment is fundamentally that of the individual patient. Express directives are taken as clear evidence of the circumstances in which the patient wishes to exercise that right. The easy translation from advance directive to the patient's right of decision, however, is not without problems. It assumes that the patient has not changed his or her mind and that the circumstances are, in relevant respects, the same as those expected when the directive was formulated. It is one thing to contemplate this course as an abstract matter far in the future, and quite another to deal with it as an immediate question. In one study of terminally ill patients, more than 60 percent supported physician-assisted suicide in a hypothetical situation, but only 10 percent seriously considered it in their own cases. Of those who did, about half changed their minds within a few months. ${ }^{66}$ Even people whose general views remain the same, cannot anticipate the exact medical situations in which they may find themselves with respect to the symptoms they may suffer and the kinds of treatments available. ${ }^{67}$

Rebecca Dresser has generalized this problem pointing out that since "illness and injury often produce significant changes in an individual's beliefs, values and goals and hence in her interests, conflicts between past and present interests and perhaps the development of a new person might not be uncommon." The incompetence itself reduces the values of "dignity, privacy and bodily integrity so precious to the competent individual." 68 If, in fact, "little psychological connectedness and continuity exists between the individual at the

65. See e.g. Conn. Gen. Stat § 19a-577, Pa. Cons. Stat. § 5833 (2005), N.C. Gen STAT \& 90-321 (2005).

66. See Ezekial J. Emanuel, et al., Attitudes and Desires Related to Euthanasia and Physician-Assisted Suicide Among Terminally Ill Patients and Their CAREgIVERS, 284 JAMA 2460, 2463-65 (2005).

67. Rebecca Dresser, Life, Death, and Incompetent Patients: Conceptual Infirmities and Hidden Values in the Law, 28 Ariz. L. Rev. 373, 376 (1986).

68. Id. at 389 . 
two points in time, then there is no particular reason why the past person, as opposed to any other person should determine the present person's fate."69 These problems are not solved by designating a particular person to make those decisions. If that person acts under the patient's prior instructions the same difficulties recur. If the surrogate exercises independent judgment the justification of acting in accordance with the patient's own decisions disappears.

(2) If there are no specific instructions from the patient (or if those instructions are thought insufficient), the law still insists that the decision on termination be attributed to the patient. This requires employment of a "substituted judgment." The term has no canonical meaning but I will use it to mean replicating the decision that the patient would make if competent. The focus, as one court described it, "must always be on what the patient would say if asked today whether the treatment in issue should be terminated."70

Many of the doubts already discussed about the reliability of express advance directives also trouble this more flexible standard. Courts have varied with respect to the detail that they require for confirming such decisions as those of the patient. In In re Quinlan, an important early case, the Supreme Court of New Jersey decided, without any individualized inquiry, that it was enough to defer to the "best judgment" of the patient's "guardian and family."71 Likewise, some statutes rely only on the relationship of the appointed decisionmakers to the incompetent patient. ${ }^{72}$ Reasoning that it is better to err on the side of preserving a patient's life, other courts have been more demanding, requiring that termination be supported by evidence of the patient's prior expressed intent. ${ }^{73}$ In Cruzan, the United States Supreme Court affirmed the constitutionality of the Missouri Supreme Court's requirement that an expressed intent of the incompetent be proven by "clear and convincing evidence."74

Most courts are willing to attribute a desire to terminate to an incompetent patient even without proof of declarations, formal or informal, on his or her views. Where there are no clear instructions, Florida law imposes a duty on the surrogate to make only those decisions "which he or she believes the principal would have made under the circumstances."75 The judgment should be based on an overall assessment of the experience and values of the patient and an estimate of how they would be applied in the present circumstances. A

69. Id. at 380-81.

70. Matter of Westchester County Med. Ctr. On Behalf Of O'Connor, 72 N.Y. 2d 517,530 (1988).

71. In re Quinlan, 355 A.2d at 664.

72. E.g. N.C. Gen. STAT. 90.322 (b) (2005).

73. Westchester County Med. Ctr., 534 N.Y.D.2d at 530-31.

74. Cruzan, 497 U.S. at 268-69.

75. FLA. STAT. $\$ 765.205(1)(b)(2005)$. 
recent codification asks the health care surrogate to "base these decisions on the surrogate's knowledge of the patient's values."76 Courts have called for evidence on the "patient's philosophical, religious and moral views, life goals, values, about the purpose of life and the way it should be lived, and attitudes toward sickness, medical procedure, suffering and death."77 On other occasions, "the impact on [the] family; the probability of adverse side effects; and the prognosis with or without treatment must be considered."78 It is evident that these numerous and elastic factors, applied in different situations, may liberate judgment as much as they constrain it.

No matter how well the surrogate decision-maker knows the patient, it is doubtful if the patient's own preferences in a particular situation are reproducible by someone else. In one study, individuals were asked how they would like to be treated in described circumstances. When potential agents were presented with these scenarios their predictions of the principals' responses were not accurate to a statistically significant degree.79 At the end, the actual decisionmaker (and any court reviewing the decision) may end up making his or her own determination about what, all things considered, is best for the patient and for other interested parties.80

(3) Such "substituted judgment," begins to merge into the third recognized ground for deciding among treatment alternatives for an incompetent patient-the patient's "best interests." Some judicial decisions and statutory schemes directly invoke this best interests standard. Others prohibit termination resulting in death unless there is at least some evidence of the patient's own preferences. In many jurisdictions, best interest is demoted to a kind of "last resort" criterion to be employed only when there is no advance directive and no grounds for inferring the patient's preferences. ${ }^{81}$ Even then, reliance on best interests is sometimes associated with the patient's own choices. ${ }^{82}$ Since people generally choose to pursue their own best interests, it makes sense to attribute to the incompetent patient a preference for the decision that a good faith decision-maker feels to be in the patient's best interests.

76. ARiz.Rev.Stat. § 36-3203(C) (2005).

77. Mack v. Mack, 618 A.2d 744, 758 (Md. 1993) (citations and internal quotation marks omitted).

78. Brophy, 497 N.E. $2 \mathrm{~d}$ at 631 (numbering omitted).

79. David Orentlicher, The Limits of Legislation, 53 Md. L. Rev. 1255, 1278 (1994)

80. John Garvey, What Are Freedoms For? 112-122 (1996).

81. E.g. ArIz. Rev. STAT. § 36-3203 (C) (2005). See also Uniform Health-Care Decisions Act, § 5(f) (1994) http://www.nccusl.org/Update/ (follow "Final Acts and Legislation"; then follow "Select a Title, Health Care-Decisions Act"). For an unusual judicial statement of the idea that best interests should be considered instead of a supposed reference to the patient's desires see the dissenting opinion of Justice Stevens in the Cruzan case. Cruzan, 497 U.S. at 338. See also Dresser, supra note 83.

82. Quinlan, 355 A.2d at 664-65. 
There are situations, however, where even this attenuated sense of the patient's own choice must be abandoned. Those are the cases of patients born with an incompetency that precludes an appreciation of their own situation or the formulation of standards of a good life. Recourse to the patient's own desires in such cases is meaningless. This puzzle did not deter the Massachusetts Supreme Judicial Court, in the well-known case of Superintendent of Belchertown State School $v$. Saikewicz. ${ }^{83}$ The patient in that case was a 67 year old man with "an IQ of ten and a mental age of approximately two years and eight months." Even then, the Court insisted that the objective was to replicate the "decision which would be made by the incompetent person, if that person were competent, but taking into account the present and future incompetency of the individual as one of the factors which would necessarily enter into the decision-making process of the competent person."84 The New York Court of Appeals, however, has recognized the futility of any attempt to capture such a patient's preferences. In one case, it quoted an expert witness who asked, "if it snowed all summer would it then be winter?"85

The fact of incompetency complicates any objective determination of best interests. The best interests of such a person are different from those of a competent person and harder for the decisionmaker to appreciate. Problems become acute where the incompetence is a result of permanent unconsciousness or a persistent vegetative state. In such circumstances a person has "no mental life at all and [is] thus unable to have any positive or negative experiences." 86 "Without awareness, expectation, beliefs, desires, aim and purpose, a being can have no interests; without interests he [or she] cannot be benefited . . .."87 It is hard to know just what a decision-maker is supposed to weigh in those circumstances.

There are less total kinds of incompetencies where, for example, the patient can experience pain, pleasure, warmth or cold. Such persons can often express their feelings and preferences by speech or otherwise. The retarded patient in Saikewicz, for example, was able to use "gestures and grunts to make his wishes known to others and respond [ed] only to gestures or physical contacts." 88 "The more mentally complex an individual is," Rebecca Dresser notes, "the more

83. 370 N.E.2d 417 (1977).

84. Saikewicz, 370 N.E.2d at 431.

85. In re Storar, 420 N.E.2d 64, 73 (N.Y. 1981).

86. See Dresser, supra note 67 at 384 (citing President's Commission for the Study of Ethical Problems in Medicine and Biomedical and Behavioral Research, Deciding to Forgo Life-Sustaining Treatment).

87. Id. at 383,383 n.58 (quoting Joel Feinberg, The Rights of Animals and Unborn Generations in Philosophy and Environmental Crisis 43, 61 (W. Blackstone ed. 1974). See also, Garvey, supra note 80 at 114 (raising same issue with respect to children).

88. SAIKEWICZ, 370 N.E. 2 d at 420. 
complex are her interests and the more numerous are the conditions that must be met if she is to live well." 89

In all of these situations, deciding which course of treatment furthers the patient's best interests (real or constructed) requires some forecast of the circumstances that would follow each alternative. This must mean that the decision-maker decides whether it would be better for the patient to live the kind of life available to him or her if treatment is maintained - or to be dead. Notwithstanding the protests of some courts that decisions must not be based on negative judgments as to the value of an impaired person's life, ${ }^{90}$ there really appears to be no other way to make the treatment choice. The third party decision-maker must decide if it would be in the best interests of a patient to be dead and, if so, what action should be taken to effectuate that decision. It is hard to see this as anything but euthanasia. By the same token, when the competent patient makes the same decision for him or herself, it is hard to see it as anything but suicide.

\section{The Law in Books and the Law in Action}

Much modern American jurisprudence has been premised on the distinction between "law in books" and "law in action." Studying the latter meant looking at what the legal system actually did rather than what legislators and judges said it did. ${ }^{91}$ Few phenomena illustrate the distinction better than the subject of this report. American law, with rare exceptions, has set its face against euthanasia, assisted suicide and suicide. At the same time it has emphatically endorsed a patient's right to terminate treatments or procedures, even when termination will speedily lead to death. In many states, moreover, this right may be exercised for incompetent patients by third parties who make a good faith determination that the patient's best interests require the action or inaction that will lead to death. Given this state of the law, decisions are made everyday to end of the lives of men and women suffering from various degrees of pain, discomfort, incapacity or humiliation, based on a conclusion that the lives in prospect are not worth living. Two conceptual devices have been deployed to rationalize this result. Each distinguishes lethal termination of life-sustaining treatment from murder and suicide.

89. Dresser, supra note 67 at 384 n.66.

90. See Saikewicz, 370 N.E.2d at 742. See also Woods, 142 S.W. 3d at 90-91 (Wintersheimer, J. dissenting). As in the case of competent patients a third party decision to terminate treatment resulting in death may be limited by the same kind of state interests discussed in Section 3. These are sometimes defined in controlling legislation as by denying such an alternative to a pregnant woman. See e.g. GA. CoDE ANN. $§ 31-32-3$ (2004) (stating in the living will that where a female has been diagnosed as pregnant the living will have no force or effect unless the fetus is not viable).

91. See Roscoe Pound, Law in Books and Law in Action, 44 AM. L. Rev. 12 (1910). 
The first distinction has already been noted. Ending medical treatment does not itself cause death. Most judicial discussions of this point track the New Jersey Supreme Court's statement in In re Conroy that "declining life-sustaining medical treatment may not be properly viewed as an attempt to commit suicide. Refusing medical intervention merely allows the disease to take its natural course ...."92 Similarly, the relevant Uniform Act proposed to the States by the National Commissioners on Uniform State Laws and the American Bar Association refers to termination decisions as "health-care" decisions like choosing between laparoscopic or conventional surgery. ${ }^{93}$ Statutes allow the removal of only "artificial" or "extraordinary" medical assistance. A fairly common locution used in defining these methods refers to things that "serve only to prolong the dying process." 94

This supposes that withholding or removing life-sustaining procedures merely restores some natural status quo and as such cannot itself be a wrongful act. According to the California Court of Appeal, in mechanical respiration or nutrition, "each pulsation. . . or each drop of fluid introduced into the patient's body . . . is comparable to a manually administered injection or item of medication." Therefore, disconnecting a machine was analogous to withholding an injection or dose of medicine-an "omission rather than an affirmative act." "[T] here is no criminal liability for failure to act unless there is a duty to act." 95 The United States Supreme Court has also averted to the "line between 'killing' and 'letting die," a "distinction widely recognized and endorsed in the medical profession and in our legal traditions. . . [and one that] comports with fundamental legal principles of causation and intent." 96

It is understandable that advocates of legal assisted suicide fail to see the relevance of these differences. In the first place, the doctor does not merely stand by when a procedure is terminated. Removal of a respirator or gastrostomy tube requires at least some planning and degree of skill. Beyond this, it is not difficult to raise hypothetical cases in which a technical difference between action and inaction has no intuitive appeal. Concurring in Cruzan, Justice Scalia noted

92. 486 A.2d 1209, 1224 (N.J. 1985). See also Vacco v. Quill, 521 U.S. 798, 801 (1996); In re Farrell, 108529 A. 2d 404, 411 (N.J. 1987) (citing cases from other jurisdictions to the same effect).

93. Uniform Health-Care Decisions Act (1994) http://www.nccusl.org/Update/ (follow "Final Acts and Legislation"; then follow "Select a Title, Health Care-Decisions Act”).

94. E.g. ALA. Code § 22-8A-3(8) (2005); D.C. Code § 7-621(3) (2005); Minn. Stat. $\S 145 \mathrm{~B} .02(8)(2005)$.

95. Barber v. Superior Court, 195 Cal. Rptr. 484, 490 (Cal. App. Ct. 1983). The court also decided that the physician, unlike a parent who is obliged to feed a child, was under no duty to provided non-beneficial care. $I d$. at 490.

96. Vacco, 521 U.S. 801. 
that "[i]t would not make much sense to say that one may not kill oneself by walking into the sea, but may sit on the beach until submerged by the incoming tide." 97

It is true that, the distinction between action and omission has been a powerful presence in common law determination of liability, both criminal and civil. ${ }^{98}$ Its persistence may reflect some idea that inaction often can be explained by inadvertence or mistake, while positive actions are, more generally, intentional. The latter, therefore, may appear more culpable. ${ }^{99}$ While that generalization may be valid for many categories of action, the "inactions" in end-of-life cases are the consequences of careful, indeed painfully deliberate, decisions. In this context, the differential legal treatment of misfeasance and nonfeasance seems contrived.

The intentionality of termination of treatment raises the second frequently cited defense for distinguishing it from euthanasia and suicide. That is the "principle of double effect." This idea, commonly associated with Roman Catholic moral theology, generally declares it permissible to perform an act that can be foreseen to have an evil effect if it is undertaken for the purpose of achieving a proper effect. ${ }^{100}$ In a standard example, a pilot bombs a village in order to destroy a munitions factory, thus shortening a war and saving lives. Although it is foreseeable that innocent civilians will be killed, the action is morally justifiable under the doctrine of double effect.101 In the end-of-life context, the principle has been cited to support the administration of pain medicine even where it will hasten the patient's death. ${ }^{102}$

Courts have used similar reasoning in reviewing termination of treatment. In deciding that such actions do not implicate the state's interest in preventing suicide they deny that the patient has the in-

97. 497 U.S. 261,296 (1990). Justice Scalia went on to suggest that a more sensible line was between "'ordinary' care and those that consist of sustaining from 'excessive' or 'heroic' measures." Id. His skepticism may have been diminished by 1997 when he joined the majority opinion in Vacco v. Quill relying in part on the traditional legal distinction between action and inaction. See also Brody, supra, note 37 at 941 42 .

98. See Jerome Hall, General Principles of Criminal Law 190-205 (2d ed. 1960); W. Page Keeton et. al., Prosser and Keeton on the Law of Torts, 373-85 (5th ed. 1984).

99. See Edward C. Lyons, In Incognito- The Principle of Double Effect in American Constitutional Law, 57 FlA. L. REv. 469, 506-07 (2005); Richard Kay, The State Action Doctrine, the Public-Private Distinction and the Independence of Constitutional Law, 10 Const. CoMm. 329, 354-57 (1993).

100. See generally Lucius I. Igorgi, The Principle of Double Effect: A Critical. ApPraisal of Its Traditional Understanding aNd its Modern Reinterpretation (1985).

101. Warren S. Quinn, Actions, Intentions and Consequences: the Doctrine of Double Effect, 18 Phil. \& Pub. Aff. 334, 334 n.3 (1989).

102. See e.g. State v. Naramore, 965 P.2d 211, 213-15 (Kan. Ct. App. 1998). Statutes frequently re-affirm the rights of patients to palliative care. See FLA. STAT. ANN. $\S 765.102$ (2005); Cal. Health \& SaFETy CoDe $\$ 1339.32$ (2005). 
tention to end his or her life. The patient intends only to remove the respirator or feeding tube, even though death will surely follow. This, according to some courts, is not the same as desiring death. $\mathrm{Pa}$ tients making this choice "may fervently wish to live, but to do so free of unwanted medical technology, surgery, or drugs, and without protracted suffering." ${ }^{103}$ The Nevada Supreme Court affirmed a competent quadriplegic patient's right to discontinue use of a respirator, an action that the trial court found "would shortly prove fatal."104 The Court declared that the patient "did not wish to commit suicide. $\mathrm{He}$ desired only to live for as long as his state of health would permit without artificial augmentation and support." ${ }^{105}$ In distinguishing termination of treatment and palliative medication from assisted suicide, the United States Supreme Court specifically referred to the fact that the former actions "may have the foreseen but unintended 'double effect' of hastening death."106

The doctrine of double effect in this context is burdened with serious difficulties. Most formulations of that principle impose a constraint of proportionality whereby the good of the intended object is not outweighed by the evil of the unintended one. ${ }^{107}$ Such an analysis would measure the injuries imposed by the unwanted treatments and compare them to the evil of hastening the patient's death. This comparison involves staggering difficulties but, in any event, no court seems to have seriously attempted it. In the case of patients lacking consciousness, it cannot be said that intravenous hydration or a feeding tube is a problem, independent of the fact that they are extending the patient's life. Even in other cases, the physical discomfort of these devices has not been described as horrific. ${ }^{108}$

Most descriptions of the doctrine also deny its applicability where the evil consequence is the means of securing the good one. ${ }^{109}$ If someone bribes an official to secure funding for a hospital, the bribe is not justified by saying that it was only the hospital that was really desired. In the example of the bombing of the munitions plant, if the pilot does not intend to shorten the war by reducing the enemy's capacity to make weapons, but rather to subvert enemy morale by killing civilians, the wrong is not excused by the principle of double effect. ${ }^{110}$ There is a difference between easing a patient's discomfort

103. In re Conroy, $486 \mathrm{~A} .2 \mathrm{~d}$ at 1224.

104. McKay v. Bergstedt, 801 P.2d 617, 620 (Nev. 1990).

105. Id. at 627.

106. Vacco, 521 U.S. at 808, n.11.

107. Warren Quinn, supra note 101 at 334 n.3.

108. David Major, The Medical Procedures for Providing Food and Water: Indications and Effects in By No EXTRAORDINARY MEANS, supra note 38, 21, 26.

109. See IGorgi, supra note 100 at 27, 38; Edward C. Lyons, supra note 99 at 482.

110. Warren Quinn, supra, note 101 at 348. Cf. Brody, supra note 37 at 946 . 
by stopping a painful procedure and easing that discomfort by "making that patient die."111

More seriously, in many termination of treatment cases, it is specious to say that death is unintended. That explanation makes sense in administration of pain medication that is foreseeably lethal. ${ }^{112}$ It is also true where the decision to terminate life support is genuinely directed to the treatment, independent of its role in keeping the patient alive. One can imagine treatments that are unrelievedly painful or that subject the patient to unbearable humiliation. We might then truthfully say that we regret the patient's death, but the rejected medical procedure itself presented an even greater evil. ${ }^{113}$ But this reasoning does not apply to many decisions to cease a life-sustaining procedure. Often what the patients or the families want to end are lives so impoverished and hopeless that they are judged not worth living. ${ }^{114}$ Despite repeated rejection of suicide and euthanasia, judicial decisions approving the right to such terminations make clear the judges' own sympathies with this judgment. The miserable existence suffered by the patient (apart form the procedure to be ended) is often described in heart-breaking detail.

At the end, the American law in action is not unlike that in many other jurisdictions. ${ }^{115}$ The taking of life is forbidden whether by the individual him or herself, or by another person. The former is not excused by pleading his or her own rights of autonomy; the latter is not excused because motivated by concern for the individual's welfare. But there are exceptions. These are generally reserved for cases where there is a good faith basis for determining that the quality of the lives to be ended has been grossly diminished-because of pain or incapacity-and there is no reasonable prospect that this condition can be reversed. In such circumstances, the actions leading to termination may be performed by the individual affected or-where that person is unable to articulate a preference-in good faith by a limited class of people who may be presumed have the patient's welfare in mind. Perhaps out of fear that other interests may improperly influence the decision, third parties may not act in to assist dying in

111. VACCO, 521 U.S. at 808.

112. But see Brody, supra, note 37 at 948 (questioning the need, in most cases, for lethal doses of analgesic in order to relieve pain).

113. See Guardianship of Jane Doe, 583 N.E. 2d 1263, 1275 (Mass. 1992) (O'Connor, J., dissenting). Edward Lyons defends the double effect justification for terminating life support without questioning the genuineness of the claim that it is only the procedures that the decision-maker wishes to end. See Edward Lyons, supra note 99 at 544-47.

114. See Glucksberg, 521 U.S. at 746-47 (Stevens, J concurring).

115. See generally Regulation of Civil Law to Safeguard the Autonomy of PAtients at the End of Their Life: An International Documentation (Jochen Taupitz, ed., 2000). 
any other way. ${ }^{116}$ Naturally, there can be honest and deeply held differences over whether the right conditions obtain in a given case, but that is not unique to this category of legal decision.

What distinguishes American law is its rhetorical commitment to the sanctity of all life and its rejection of the idea that some lives are not worth living. ${ }^{117}$ The litigated cases involving a decision to allow the patient to die are therefore premised not on a right to die or a right to take life in defined circumstances, but on the right to control one's own body by refusing medical treatment. This obfuscation has been far from easy, as the cases attempting to apply the right to people without decision-making capacity illustrate. Relatively recent statutory regulations are more direct in specifying the appropriate circumstances in which life-saving treatment may be discontinued. A few, moreover expressly refer to the right at issue as one "to a peaceful and natural death."118 Generally, they obscure matters, however, by founding their options expressly on the right to make decisions about medical treatment ${ }^{119}$ and condemning suicide or euthanasia. ${ }^{120}$ If we suppose that the rules are really being formulated to control what are, in pith and substance, life-ending actions, this approach can only confuse judgment.

The common law, however, has never been a slave to rationality. Perhaps its leading characteristic has been its capacity to adapt doctrines developed in one context to rather different circumstances. Its inherent conservatism manifests itself in its reluctance to abandon old categories and concepts even when they cease to speak to contemporary problems. Instead it simply declares that they apply to new and apparently inapt instances. A injured child who trespassed on property to which he was attracted by a dangerous situation should have an action for damages against the property owner. So although entirely unknown to the owner, he became an "invitee."121 Henry Maine described the likely reasons for such circumlocutions in his discussion of legal fictions: "They satisfy the desire for improvement, which is not quite wanting, at the same time that they do not offend the superstitious disrelish for change which is always present."122

116. The sole exception is the Oregon Death with Dignity Act, Or. Rev. Stat. $\S \S 127.800-127.890$ (2005). That law speaks to the needs to limit such actions to cases of seriously reduced quality of life and to avoid improper influence by specifying an elaborate procedure to be followed before a lethal prescription may be written. Id.

117. See John Robertson, Schiavo and Its (In)Significance, University of Texas School of Law Public Law and Legal Theory Research Papers, No. 72, 22-24, http:// ssrn.com/abstract $=692901$ (visited Jan. 11, 2006).

118. N.C. Gen. Stat. \& 90-320(a) (2005).

119. E.g. Uniform Health-Care Decisions Act, Prefatory Note, \$1(6); Fla. STAT. $\S 765.102(1)(2005)$.

120. E.g. Ariz. Rev. Stat. §36-3210 (2005); Minn. Stat. §145B.15 (2005); Ky. Rev. StAT. ANN. § 311.639 (Lexis 2005).

121. KeEton ET. AL., supra note 98 at, 69-72.

122. Henry Sumner Maine, Ancient Law 25 (Henry Holt 1874) (1869). 
Maine seemed to think that, as law became more rational, a more clear-headed process of legal change would emerge ${ }^{123}$ and with regard to many areas of regulation he was right.

But the law on compassionate death shows that there may be other reasons for maintaining disingenuous descriptions of legal devices. Notwithstanding what appears to be a widespread practice of allowing individuals or families to decide that a certain life should not continue, an overt adoption of that policy would engage passionate political and moral differences. Explicit legal machinery for ending lives would be in tension with what has come to be called the "culture of life." That policy has been associated with opposition to abortion, to human cloning and, more recently, to stem-cell research. ${ }^{124}$ For many Americans, it has been important to be able to end the suffering of loved ones while clinging to a belief in the sanctity of life. If the current state of the law is not a result of that difficulty, it certainly helps to relieve it. ${ }^{125}$

The cost, as students of legal fictions have pointed out, ${ }^{126}$ is obscurity in the governing rules and obstacles to articulating a policy better reflecting considered judgments as to the circumstances in which the deliberate ending of life is acceptable. With the exception of cases in which those closest to the patient are in disagreement, however, the current state of affairs seems to yield results that are widely felt to be tolerable. For many people, a more direct route to a similar state of affairs would require a painful examination of their personal and social values, as well as extended contemplation of their mortality. Avoiding that may be worth a muddled law. ${ }^{127}$

123. See generally id. at 21.

124. http://www.whitehouse.gov/infocus/achievement/chap15.htm (last visited Jan. 11, 2006). The idea might more properly be defined as a concern for innocent human life as its advocates tend to be strong proponents of capital punishment. See Ronald Brown Stein, 'Culture of LifE' Issues Split GOP. Los Angeles Times, Mar. 28, 2005 , at A1.

125. "[T]he judges do not have to put the utilitarian analysis down on paper; they do not want to say things about the incompetent that no one wants to say; things reflecting an attitude that the incompetent is something less than a person-or something less than alive." Louise Harmon, Falling Off the Vine: Legal Fictions and the Doctrine of Substituted Judgment, 100 Yale L.J. 1, 61 (1990).

126. See generally Pound, supra note 91 ; Harmon, supra note 125 at 63 n.260 ("[T]hose deeply disturbing moral issues should be examined by the light of day, not hidden in the dark.")

127. See Robertson, supra note 117 at 18 (noting that legal obfuscation in this case results from being caught "between Louis Brandeis' dictum that 'the best disinfectant is sunlight' and T.S.Eliot's reminder that 'humankind cannot bear too much reality.'). 